\title{
OBITUARY
}

\section{GORDON WILKINSON GOODHART}

Dr. G. W. Goodhart, M.D., F.R.C.P., Bunny Goodhart as most of his friends liked to think of him, died in London on July 16 just before his 66th birthday. He was the younger son of Sir James Goodhart, a consulting physician in the great Victorian tradition. He was educated at Westminster School, Trinity College, Cambridge, and Guy's Hospital, graduating M.B. in 1908. At Guy's he became successively house-physician, Gull research student, Douglas demonstrator in pathology, and senior assistant bacteriologist. Subsequently he worked in Berlin, and for a time with Aschoff at Freiburg, returning to become clinical pathologist at University College Hospital. In the 1914-18 war he was in France with the R.A.M.C., and served as pathologist to the Second London General Hospital. In the following years at University College Hospital, apart from teaching students and his own junior staff, he carried on continuous research with Charles Bolton on gastric secretion and constantly helped and stimulated the fundamental work of Price Jones on red cell size. In 1931 he was appointed as one of the first four pathologists to the London County Council, and he did much to establish and develop their highly successful service. He worked first at the Archway Group Laboratory and then at St. Mary Abbots. He was in due course President of the Section of Pathology of the Royal Society of Medicine, of the Medical Society of London, and of the Association of Clinical Pathologists. To this Association in its early years he gave unfailing help and encouragement.

Physicians and surgeons were always to be found in Goodhart's laboratory at University College Hospital, or later in his London County Council laboratories, discussing their problems with him. He himself was constantly to be seen in the wards looking at the patients. The knowledge he gained in his laboratory only became real to him in relation to the individual patient. Case reports or pathological reports alone were meaningless and both must be interpreted in relation to the actual human being. So he taught a succession of students, assistants, and colleagues, for from his early days at U.C.H. all medical students served a three months' clerkship in his department. This, though now an accepted procedure in medical

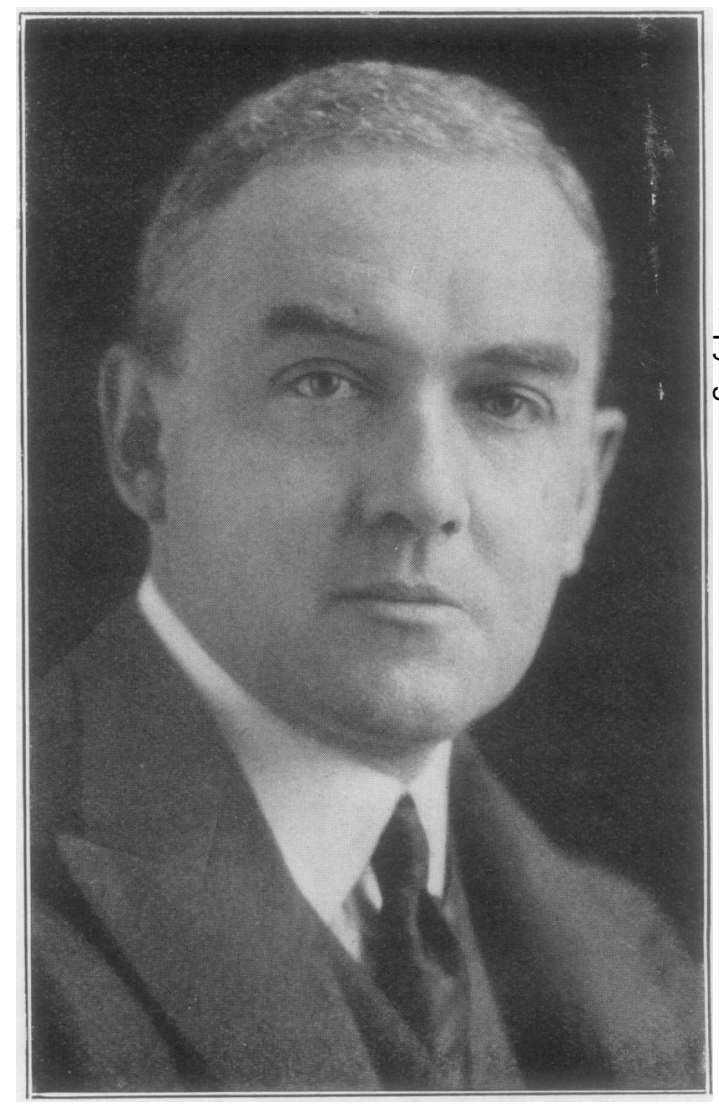

\section{GORDON WILKINSON GOODHART}

training, was an innovation, part of Goodhart's contribution to the medicine of his time. Many of his pupils practising in very different fields to-day when they meet agree that Bunny Goodhart taught them what really mattered in their medicine. His original contributions to knowledge were all sound, but so much of what he had learnt by careful observation 
and experience he never wrote down but handed on in his day-to-day teaching and conversation. This is especially true in the expanding field of haematology.

During the last five years he was often very ill, but he carried on with a courage and gaiety that will always be an inspiration to remember. His hospital might quite literally be brought down on top of him, but there he still was ready to help both with medical and personal problems. Still finishing the last story, he saw one out over the heaps of rubble just as in safer days he had seen one down the laboratory stair. Those long stories were very much part of the man: they were never unkind, they were often shrewd, and he told them with such evident enjoyment himself that the listener enjoyed them too.
Gordon Goodhart had a fine mind but no great ambition to achieve academic or worldly distinction. He was content to do his day's work well, to return after tea to an exceedingly happy home with his wife and their three children, to keep alive a host of friendships; but when the medical history of the early twentieth century comes to be written he will be remembered as one of the leaders of a small group of men who, because of their own skill as physicians combined with their love and understanding of the more precise discipline of the laboratory, created that hybrid despised by some but none the less essential to the developing medical sciences-the clinical pathologist. His friends to-day miss him and will remember him as, in the fullest sense of the words, "a beloved physician."

JaNet Vaughan.

\section{REVIEWS}

Pathologische Anatomie und Chemotherapie der Infektionskrankheiten. By Gerhard Domagk. Stuttgart : Georg Thieme Verlag. 1948. Pp. 424. 133 illustrations. Price, bound, D.M. 48.

Hardly more than a generation has passed since British medicine looked to Germany for inspiration and for advanced books, perhaps in no branch of medical science more than in the field of pathology. English textbooks are now as eagerly sought by medical students in most parts of the world. Nevertheless a new publication in German still evokes the interest of British students and research workers, especially one from the pen of Professor Domagk, whose name is so closely associated with pioneering research on the sulpha drugs. The general plan of relating the action of the antibacterial drugs to the pathological process of infection with a detailed study of the tissue changes is a good one and is well done. The student will also benefit from the author's classification of infections from a pathogenetic point of view, although this classification should not be regarded as rigid. The disturbing feature of the book is that, although the title suggests a wider field, in fact only bacterial diseases are dealt with and even they are not fully covered. The reader will progressively come to realize that the term "infectious disease" is here used almost synonymously with those infections which are affected by the sulpha drugs. The book is, in fact, a survey of sulphonamides and covers a wide field of research into their uses and actions: as such it is an excellent reference book. The author may naturally have stressed his own particular interests, but the need for full information on all modern antibiotics and their uses and limitations is urgent, particularly for German doctors who have had till now such slight experience of penicillin, streptomycin, etc., and who may be given a one-sided impression by this book. It is to be hoped that this deficiency will be remedied in the next edition.

\section{H. G. KoHLER.}

British Drug Houses have produced a pamphlet entitled "Introductory Notes on Chromatography," which they are prepared to send without charge to clinical pathologists who may be interested in this subject. The monograph is clearly meant to cover as wide a range as possible. Those interested in the specific aspect of the field will find the bibliography useful.

Nicholas Martin. 